MaPan : Jurnal Matematika dan Pembelajaran

p-ISSN: 2354-6883 ; e-ISSN: 2581-172X

Volume 9, No 2, Dec 2021 (304-319)

DOI: https://doi.org/10.24252/mapan.2021v9n2a8

\title{
ANALYSIS OF ELEMENTARY SCHOOL STUDENTS DIFFICULTIES' IN SOLVING INTEGER WORD PROBLEMS
}

\author{
Chusnul Ainia1), Mohammad Faizal Amir ${ }^{2)}$ \\ 1,2Elementary School Teacher Education Study Program, Universitas Muhammadiyah Sidoarjo \\ 1,2J1. Mojopahit 666 B Sidoarjo, Indonesia \\ Email: chusnul.umsida@gmail.com¹), faizal.amir@umsida.ac.id²)
}

Received November 25, 2021; Revised December 26, 2021; Accepted December 27, 2021

\begin{abstract}
:
This type of research is descriptive qualitative with a case study approach. This study aimed to identify forms of students' conceptual and principle difficulties in solving integer story problems. The research participants were 34 fifth-grade elementary students. The purposive sampling technique was used to select research subjects based on the minimum completeness criteria value. Methods of data collection using tests and interviews. Data analysis techniques include data reduction, data presentation, and drawing conclusions. The results showed that there were two types of difficulties for elementary school students in solving integer story problems, namely, conceptual difficulties and principle difficulties. The form of conceptual difficulties experienced by students is the difficulty in converting story problems into mathematical form. Besides that, students tend not to write down the steps according to solving story problems, and the principal difficulties experienced by students include errors in performing mathematical calculations. This can be minimized by increasing practice questions in the form of story problems.
\end{abstract}

Keywords: Difficulty, Word Problems, Integers

\section{ANALISIS KESULITAN SISWA SEKOLAH DASAR DALAM MENYELESAIKAN MASALAH CERITA BILANGAN BULAT}

\begin{abstract}
Abstrak:
Jenis penelitian ini adalah deskriptif kualitatif dengan pendekatan studi kasus. Tujuan penelitian ini adalah untuk mengidentifikasi bentuk-bentuk kesulitan konsep dan prinsip siswa dalam menyelesaikan masalah cerita bilangan bulat. Partisipan penelitian adalah 34 siswa kelas $\mathrm{V}$ sekolah dasar. Teknik purpose sampling digunakan untuk memilih subjek penelitian dengan berdasar nilai kriteria ketuntasan minimal. Metode pengumpulan data menggunakan tes dan wawancara. Teknik analisis data meliputi reduksi data, penyajian data, dan penarikan kesimpulan. Hasil penelitian menunjukkan bahwa terdapat dua jenis kesulitan siswa sekolah dasar dalam menyelesaikan masalah cerita bilangan bulat, yaitu kesulitan konsep dan kesulitan prinsip. Bentuk kesulitan konsep yang dialami oleh siswa adalah kesulitan dalam mengubah masalah cerita ke bentuk matematika selain itu siswa cenderung tidak menuliskan langkah-langkah sesuai penyelesaian masalah cerita, dan bentuk kesulitan prinsip yang dialami oleh siswa antara lain kesalahan dalam melakukan
\end{abstract}

Copyright @ 2021, MaPan : Jurnal Matematika dan Pembelajaran 
perhitungan matematika. Hal tersebut dapat diminimalisir dengan cara memperbanyak latihan soal yang berbentuk masalah cerita.

Kata Kunci: Kesulitan, Masalah Cerita, Bilangan Bulat

How to Cite: Aina, C., \& Amir, M. F. (2021). Analysis of Elementary School Students Difficulties' in Solving Integer Word Problems. MaPan : Jurnal Matematika dan Pembelajaran, $9(2)$, 304-319. https:/ / doi.org/10.24252/mapan.2021v9n2a8.

\section{INTRODUCTION}

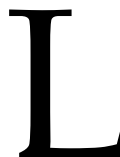

earning mathematics at every level of education aims to practice problem-solving skills through problems close to students' daily lives (Culaste, 2011; Zalima, Njanji, Lasmiatik, Agustina, \& Dela, 2020). Problem-solving is an essential skill for students to learn mathematics meaningfully (Nur, Kartono, Zaenuri, \& Rochmad, 2020; Saja'ah, 2018). Students' problem-solving skills include the ability to read problems, understand the meaning of the problem, be able to write down what is known and what is asked, be able to determine the formulas to be used, calculate based on formulas, or perform arithmetic operations accurately, and the ability to find answers correctly (Lutvaidah \& Hidayat, 2019).

Problem-solving skills in elementary schools are needed so that students are said to have competence in understanding mathematical concepts, explaining the interrelationships between concepts, and applying concepts or algorithms flexibly, accurately, efficiently, and precisely in solving problems themselves in everyday life (Sidik \& Wakih, 2019; Sovia \& Herman, 2019). In order to solve problems in mathematics, problems are presented in the form of word problems (Laily, 2014; Verschaffel, Schukajlow, Star, \& Dooren, 2020). Word problem-solving skills for elementary school students require knowledge of mathematics and an understanding of language (Mulyati, 2016; Sepeng \& Madzorera, 2014).

However, based on previous studies, elementary school students have difficulty solving word problems in terms of concepts and principles (Levin, 2018; Mandasari \& Rosalina, 2021). There are several types of student difficulties in solving integer set problems, including fact, concept, operating, and principle difficulties (Aliah \& Bernard, 2020; Bryant, Bryant, Bryant, Dougherty, Roberts, Pfannenstiel, \& Lee, 2020). There are several types of 
difficulties in solving mathematical problems, including difficulties in understanding the problem, determining a solution strategy, making mathematical models, and performing mathematical procedures (Dewi, Untu, \& Dimpudus, 2020). There are three types of student difficulties in solving problems, including difficulties in using concepts, difficulties in using principles, difficulties in solving verbal problems. Some students even have difficulties in solving word problems on building materials, including failure to imagine shapes and geometrical nets, difficulty in performing multiplication operations as well as difficulties in understanding the meaning of the editorial questions presented in the form of word problems (Padang, Fuad, \& Ekawati, 2018; Pujiastuti, 2021).

The difficulty in solving the word problems refers to the difficulties of the concept and the principle. Concept difficulty is the inability of students to infer information from a given concept, the failure of students to state the meaning of terms that represent certain concepts. In comparison, the principal difficulties are students' inaccuracy in mathematical calculations or operations, students' inability to abstract patterns (Achmetli, Schukajlow, \& Rakoczy, 2018; Dewi, Untu, \& Dimpudus, 2020).

Elementary school students still have difficulty solving word problems on integer arithmetic operations. The low understanding of students about integer operations causes students to have difficulty solving integer operations problems related to mathematical concepts and principles (Mandasari \& Rosalina, 2021). Students often experience difficulties determining the arithmetic operation to be used and difficulties working on word problems because they cannot understand the meaning of the questions. In learning integer operations, students are still not able to do well, are still not thorough in working, and seem very rushed (Mahmuda, Astuti, Mikdadi, Saputra, \& Darmadi, 2021; Sipayung \& Anzelina, 2019).

Based on the description above, elementary school students have difficulty solving word problems due to the concepts and principles difficulty. The difficulty is also influenced by habit in the case of prejudice, which is mainly based on colloquial meanings (Purwaningtyas, Sari, \& Artharina, 2020). In addition, existing studies have not specifically analyzed the form of concept difficulties and what principles elementary school students do in solving word problems on integer arithmetic operations. So it is deemed necessary to identify variations in the forms of difficulty of concepts and principles faced by elementary school students in solving word problems on 
integer arithmetic operations. This is possible because students have different ways or methods of solving problems related to problem-solving (Waskitoningtyas, 2016). Thus, this study aimed to analyze the forms of difficulty of concepts and principles of elementary school students in solving word problems on the material of integer arithmetic operations.

\section{METHODS}

This research method is qualitative with a case study approach. Qualitative research is a research method that seeks to describe and interpret objects naturally (Astawa, Suarjana, \& Murda, 2016). A case study is a research approach that carefully investigates a particular program, event, activity, process, or group (Creswell, 2012). The stages of the case study carried out in this study are shown in figure 1.

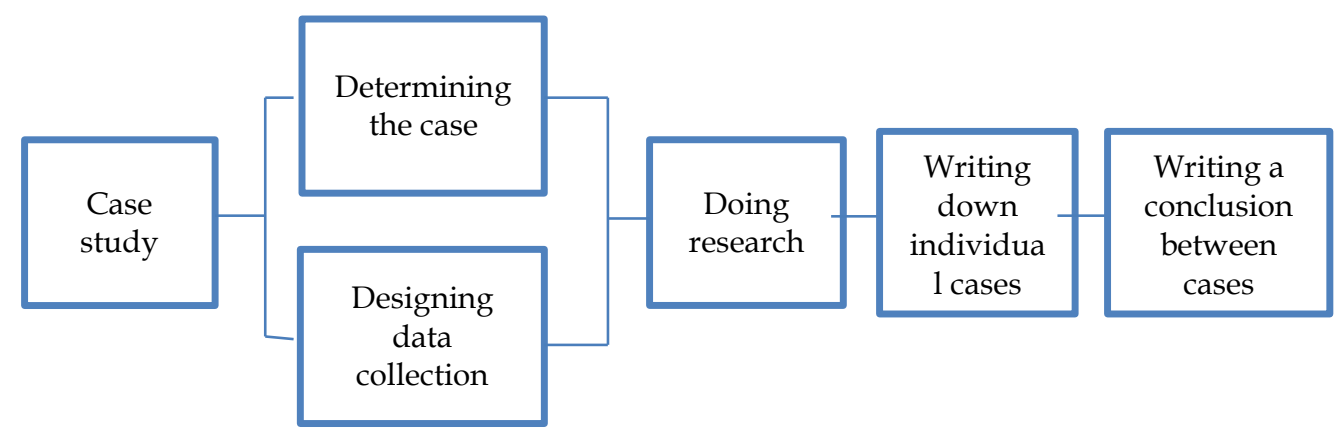

Figure 1. Case Study Process

The participants of this study were 34 fifth-grade students of SD Negeri Kenongo 1 Tulangan Sidoarjo. Using the purposive sampling technique, 7 students were taken as research subjects. The purposive sampling criteria in this study are students who have a written test score for word problems in integers that is less than the standard value of the minimum completeness criteria that has been set, which is $<79$.

The instruments used include written tests and interview guidelines. The written test is in the form of word problems, which consist of 5 problems on integer operation material, namely: problem 1 regarding the temperature rise, problem 2 for calculating the height of the jump, problem 3 for determining the presence of a person, problem 4 for calculating the height of the jump, and problem 5 for calculating the score obtained (See Table 1). The purpose of giving a written test is to determine the location and form of students' difficulties. After completing the test, interviews were conducted 
using interview guidelines on selected subjects to dig deeper information regarding the difficulties experienced by students.

Table 1. Word Problems Test

Number $\quad$ Test Description
The teacher invites her students to experiment to measure the
temperature of a piece of ice. The initial temperature of the ice is -
$5^{\circ} \mathrm{C}$. After heating, the ice turns into the water at $3^{\circ} \mathrm{C}$. How much
does the ice rise to water?
A dolphin is swimming at a depth of 8 meters below sea level. The
dolphin jumps to a height of 20 meters above sea level. How high
does the dolphin jump?
Dela works in an office with 25 floors above ground and 3 floors
underground. Dela is in the elevator on the 5 th floor. She goes
down 7 floors to deliver the goods. After delivering the goods, he
had to go up to another 15 floors to give a report. On which floor
did Dela report?
Ibrahim is a diving athlete. He jumps from a diving board as high
as 12 m, then slides to a depth of 2 m below the surface of the
swimming pool. How high did Ibrahim jump down?
In a math quiz competition, the committee ruled that each correct
answer was given a score of 5 , incorrect answers were given a score
of -2, and questions that were not answered were given a score of
0. Of the 50 questions given, Linda answered 35 questions
correctly, 5 questions incorrectly, and 10 unanswered questions.
What score did Linda get?

The data analysis technique uses data reduction, data presentation, and conclusion drawing (Miles, Huberman, \& Saldana, 2013). The first step is to reduce the data, which is to group students according to the difficulty form based on the results of the answers that have been done. Students with scores less than the minimum completeness criteria were taken to be interviewed to obtain information about the difficulties they experienced. The indicators of the type of difficulty can be seen in table 2. The second stage is the presentation of the data, namely displaying the results and discussion of research obtained from the data reduction stage. The third stage is concluding, namely concluding the results and related discussions in this study. Source triangulation is used to check the validity of the data. 
Table 2. Difficulty Form Indicators

\begin{tabular}{|c|c|}
\hline Difficulty Type & Difficulty Form Indicators \\
\hline Concept & $\begin{array}{l}\text { - The inability of students to infer information from a } \\
\text { given concept }\end{array}$ \\
\hline Difficulty & $\begin{array}{l}\text { - The inability to state the meaning of terms that } \\
\text { represent certain concepts }\end{array}$ \\
\hline Principle & The inaccuracy in calculations or operations \\
\hline Difficulty & - The inability of students in abstracting patterns \\
\hline
\end{tabular}

\section{RESULTS AND DISCUSSION}

The results of the study were taken from 34 fifth-grade elementary school students. The researcher selected seven students who were used as subjects by examining the work of students who scored less than the minimum completeness criteria. Student scores in this study are presented in table 3.

Table 3. Research Subjects

\begin{tabular}{cc}
\hline Student Code & Score \\
\hline S2 & 40 \\
S4 & 55 \\
S6 & 70 \\
S8 & 70 \\
S10 & 55 \\
S13 & 25 \\
S14 & 55 \\
\hline
\end{tabular}

The results of the research subject's work in writing were analyzed, then confirmation was carried out in the form of interviews. Figures 2 to 6 showed an analysis of the difficulties of concepts and principles experienced by the subject in writing. 


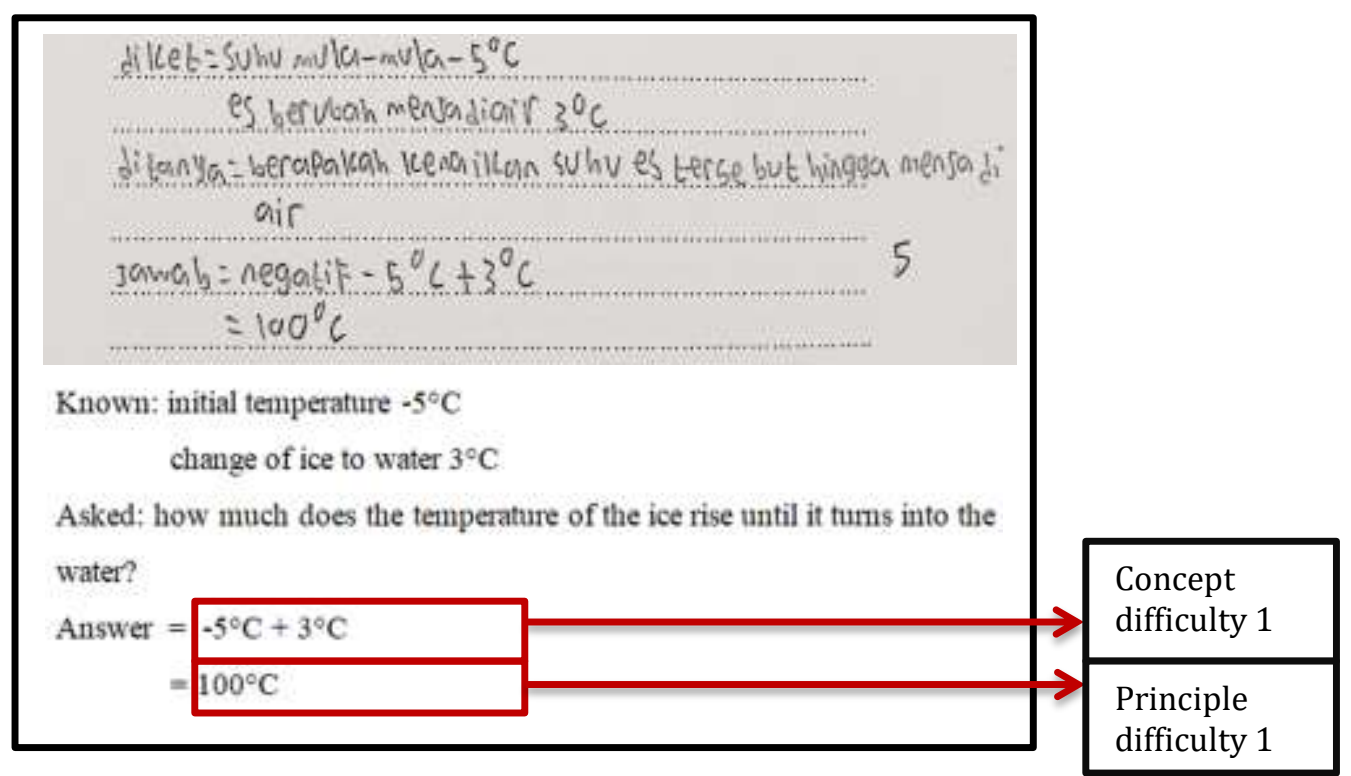

Figure 2. The Difficulty of Concepts and Principles in Problem Number 1

Figure 2 shows the difficulty of concept 1 in problem number 1 . Namely, the student wrote the wrong mathematical form. The difficulty of the concept occurred in $\mathrm{S} 13$ because students should write $3^{\circ} \mathrm{C}$ first, then subtract $5^{\circ} \mathrm{C}$ (number $-5^{\circ} \mathrm{C}<3^{\circ} \mathrm{C}$ ). So the correct answer is $8^{\circ} \mathrm{C}$ which is the result of $3^{\circ} \mathrm{C}$ $-\left(-5^{\circ} \mathrm{C}\right)$. The concept difficulty 1 in problem number 1 was also experienced by S8, S14, S2, and S6 because their mathematical writing form was similar to S13. S13, S8, S14, S2, and S6 have difficulty with principle 1. Namely, students make mistakes in calculating the final result. This statement is reinforced by the results of the interview obtained. S2 said, "yes, I am still confused about writing down the mathematical form." When asked why $-5^{\circ} \mathrm{C}$ was written at the front, S2 said, "I think that the number that appears first in the story problem is placed at the beginning of the writing in the mathematical solution." In this case, S2 only accepts rote knowledge and does not understand the concept. In addition, S2 said, "I am careless in writing answers." When asked how do you calculate and get a result of 100. In this case, S2 is not careful in calculating the final result and is in a hurry to solve the problem. 


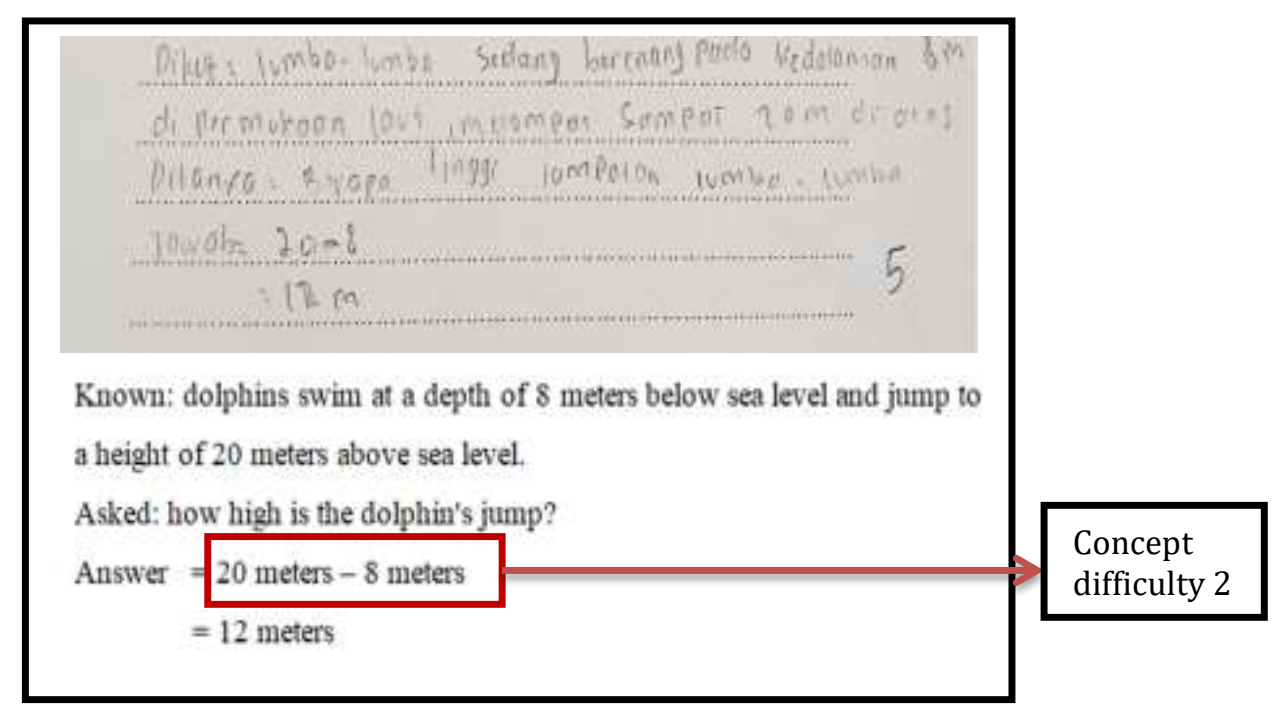

Figure 3. The Difficulty of Concepts in Problem Number 2

Figure 3 shows the difficulty of concept 2. Namely, students misunderstand the meaning of the problem. Difficulties occurred in S13 because S13 did not write a minus sign or a (-) sign before the number eight (8). The number eight should be given a minus sign (-). Because in the word problems there was the word "below sea level" the correct answer is $20-(-8)=$ $20+8=28$ meters. S14 also experienced the difficulty of this concept. This statement is reinforced by the results of the interviews obtained. S13 said, "yes, I often forget to write negative if there are words below the surface in the story." When asked why the number 8 is positive, S13 said, "I am still confused in understanding the meaning of the question." In this case, S13 had difficulty understanding the meaning of the problem, so that in writing the mathematical form, an error occurred.

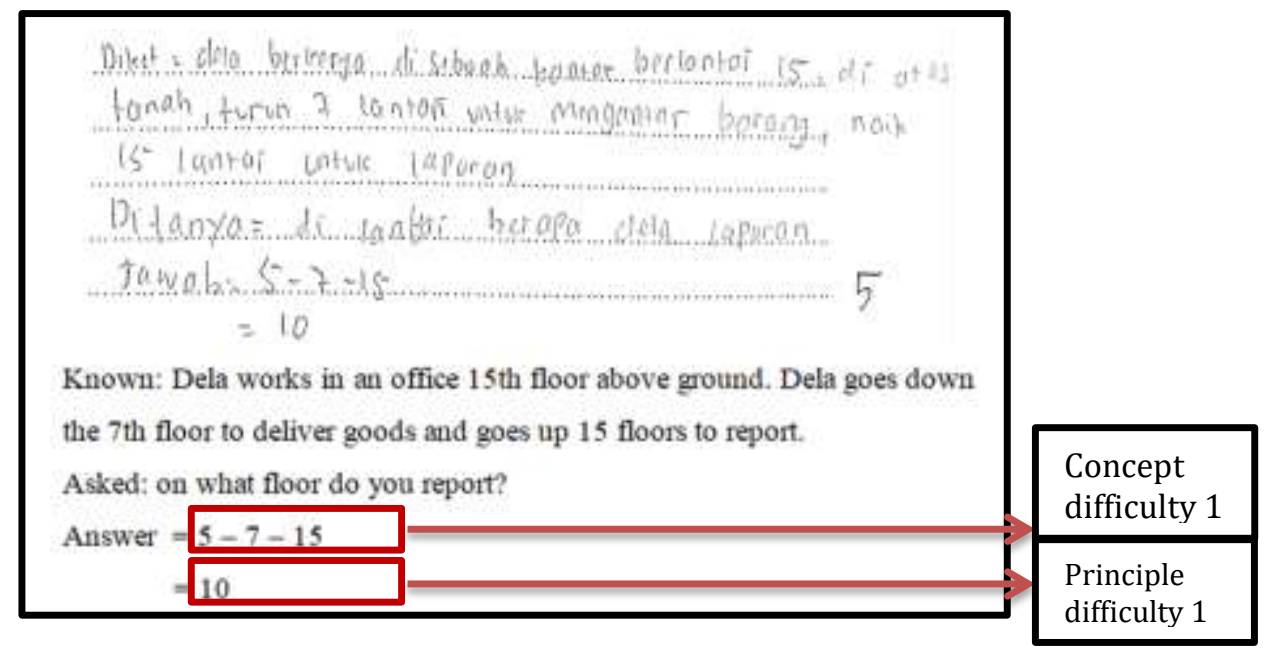

Figure 4. The Difficulty of Concepts and Principles in Problem Number 3 
Figure 4 shows the concept difficulties in problem number 3, namely S2, S4, S10, incorrectly in writing mathematical forms. In this case, S2 and S4 also had difficulty with principle 1 being wrong in calculating the results. This happened to S2, S4, S10, who had written the completion steps coherently, but there was an error in calculating the final result. This statement is reinforced by the interview results obtained. S13 said, "yes, I was confused when writing arithmetic operations." When asked why he wrote the subtraction operation after the number 7, S13 said, "I think there is a descending word in the question." In this case, S13 is less thorough in reading the questions and has difficulty writing mathematical arithmetic operations. In addition, S13 said, "I saw a friend's answer." When asked how do you calculate and get a result of 10. In this case, S13 was in a hurry to solve the problem because he saw that all his friends had finished.

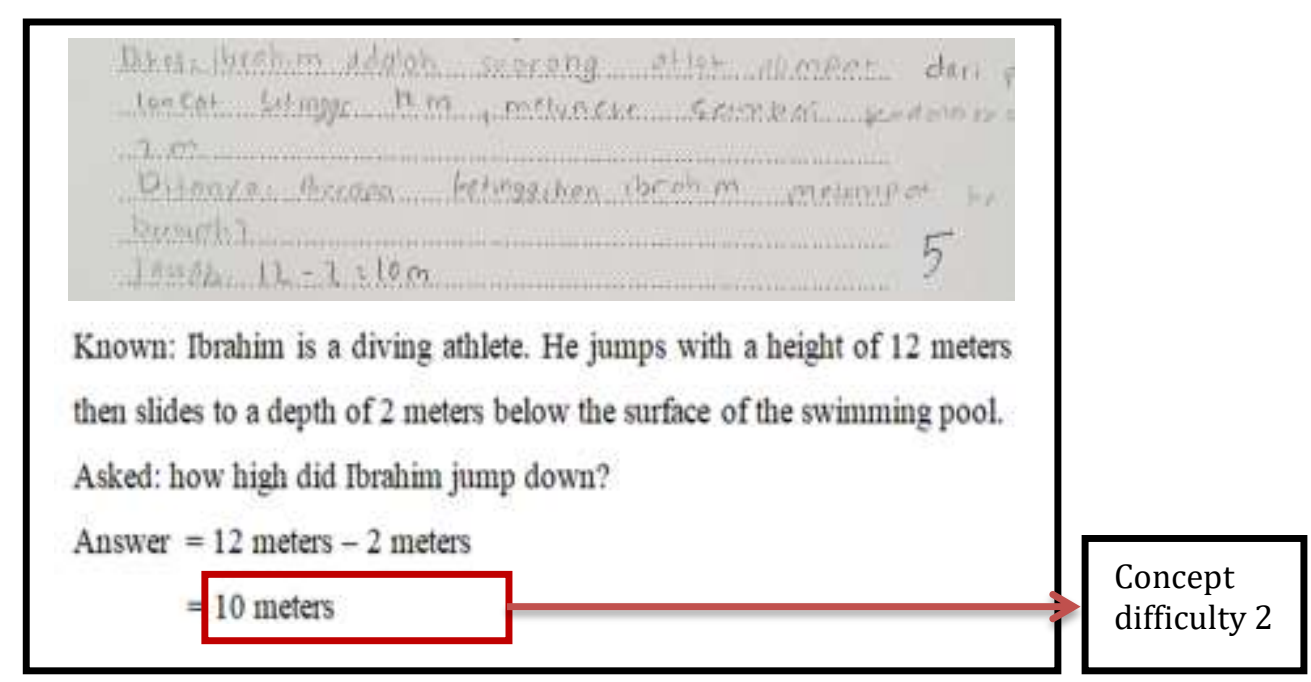

Figure 5. The Difficulty of Concepts in Problem Number 4

Figure 5 shows the difficulty of concept 2. Namely, students misunderstand the meaning of the problem. The difficulty occurs in S13 in problem number 4 because it did not write a minus sign or sign (-) before the number two (2). The number two should be given a minus sign (-) in word problems. There was the word "below sea level" the correct answer is $12-(-2)$ $=12+2=14$ meters. S2, S14, and S8 also experienced the difficulty of this concept. This statement is reinforced by the results of the interviews obtained. S13 said, "yes, I often forget to write negative if there are words below the surface in the story." When asked why the number 2 is positive, S13 said, "I am still confused in understanding the meaning of the question." In this case, S13 
had difficulty understanding the meaning of the problem, so that in writing the mathematical form, an error occurred.

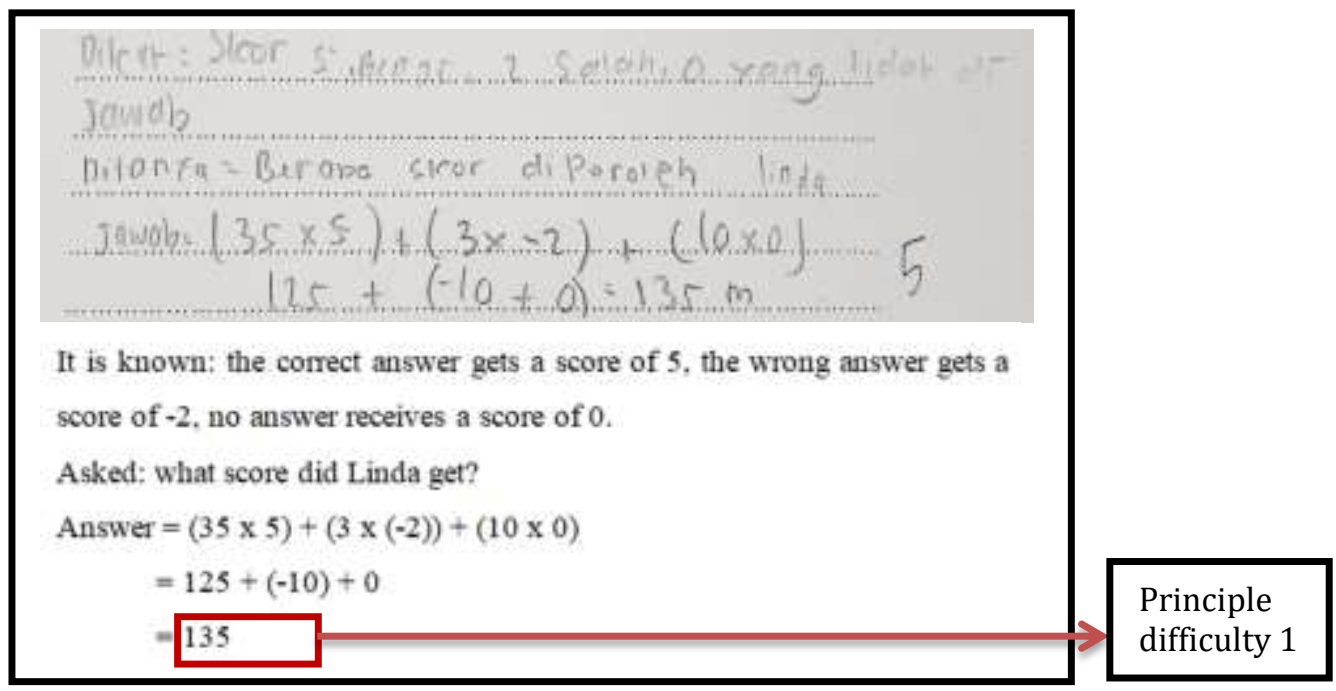

Figure 6. The Difficulty of Principles in Problem Number 5

Figure 6 shows the difficulty of principle 1, namely, students experienced errors in calculating results. This happened in S13, where students had coherently written the completion steps, but there was an error in calculating the final result. This principle difficulty was also experienced by subjects S2, S6, S4, and S10. This statement is reinforced by the results of the interview obtained. S13 said, "yes, there was an error in calculating the multiplication of $35 \times 5$." When asked why he wrote 125 out of $35 \times 5$, in this case, S13 was not careful in calculating the results, so there was an error in writing the final result.

Thus, there are two forms of students' difficulties in solving integer word problems, including conceptual and principle difficulties. Each difficulty type has a difficult form, including conceptual difficulties, namely errors in writing mathematical forms and mistakes in understanding the meaning of the problem. Meanwhile, the principle difficulty experienced was an error in calculating the final result. The synthesis of the analysis results of types and forms of difficulty in solving integer word problems are in table 4. 
Table 4. Synthesis of Difficulty Forms Word Problems Integer

\begin{tabular}{|c|c|c|c|}
\hline $\begin{array}{l}\text { Problem } \\
\text { Number }\end{array}$ & Question Form & $\begin{array}{c}\text { Difficulty } \\
\text { Type }\end{array}$ & Difficulty Form \\
\hline \multirow{2}{*}{1} & \multirow[t]{2}{*}{$\begin{array}{l}\text { Determining the } \\
\text { temperature rise }\end{array}$} & $\begin{array}{l}\text { Concept } \\
\text { difficulty } 1\end{array}$ & $\begin{array}{l}\text { Error writing mathematical } \\
\text { form }\end{array}$ \\
\hline & & $\begin{array}{l}\text { Principle } \\
\text { difficulty } 1\end{array}$ & Error in calculating results \\
\hline 2 & $\begin{array}{l}\text { Calculating jump } \\
\text { height }\end{array}$ & $\begin{array}{l}\text { Concept } \\
\text { difficulty } 2\end{array}$ & $\begin{array}{l}\text { Misunderstanding the } \\
\text { meaning of the problem }\end{array}$ \\
\hline \multirow{2}{*}{3} & \multirow{2}{*}{$\begin{array}{l}\text { Determining } \\
\text { someone's } \\
\text { whereabouts }\end{array}$} & $\begin{array}{l}\text { Concept } \\
\text { difficulty } 1\end{array}$ & $\begin{array}{l}\text { Error writing mathematical } \\
\text { form }\end{array}$ \\
\hline & & $\begin{array}{l}\text { Principle } \\
\text { difficulty } 1\end{array}$ & Error in calculating results \\
\hline 4 & $\begin{array}{l}\text { Calculating jump } \\
\text { height }\end{array}$ & $\begin{array}{l}\text { Concept } \\
\text { difficulty } 2\end{array}$ & $\begin{array}{l}\text { Misunderstanding the } \\
\text { meaning of the problem }\end{array}$ \\
\hline 5 & $\begin{array}{l}\text { Calculating the } \\
\text { score obtained }\end{array}$ & $\begin{array}{l}\text { Principle } \\
\text { difficulty } 1\end{array}$ & Error in calculating results \\
\hline
\end{tabular}

The findings of the difficulties experienced by the seven selected subjects are in Table 4, namely: students experience two types of difficulties, namely conceptual difficulties and principle difficulties. The results of the analysis that has been carried out on seven subjects showed that student difficulties occur in any given problem, including problems number 1 and 3 that students tend to have conceptual difficulties and principle difficulties. Students tend to have conceptual difficulties in problems number 2 and 4 . Finally, students tend to have difficulties in principle on problem number 5.

The findings in this study are a form of concept difficulty consisting of errors in writing mathematical forms and mistakes in understanding the meaning of the problem. Difficulties in using concepts often occur because the learning process of mathematics has not been meaningful, so students' understanding of mathematical concepts is feeble (Al-Mutawah, Thomas, Eid, Mahmoud, \& Fateel, 2019; Evi, 2011; Song, 2018). While the form of principle difficulty in the form of errors in calculating the results. The findings of this study are similar to previous studies that students are less thorough in their ability to read problems, understand problems and when counting are still inaccurate, and solve problems in a hurry (Wulandari \& Riajanto, 2020). Difficulty in understanding the meaning of the problem is seen from writing errors every step of the process (Syahrir, Kusnadin \& Nurhayati, 2013). 
The principal difficulty of students experiencing errors in calculating the final results can be seen from the weakness of students in solving problems in the form of stories at the stage of re-examining (Aliah \& Bernard, 2020). Students' difficulties in solving math problems can be seen from the students' mistakes in doing math problems. The factors that cause students to have difficulty are because students cannot understand the meaning of the problem sentence, and students are not careful in reading the problem (Saja'ah, 2018). Students cannot express meaning and apply existing principles (Fatahillah, N.T \& Susanto, 2017). In addition, the difficulty of using the principle is marked by students' difficulty in carrying out discovery activities about something and the difficulty of determining the relevant factors. As a result, students cannot abstract the patterns (Pubaningrum, 2019).

\section{CONCLUSION}

The analysis results showed that students had difficulty with concepts and principles in solving word problems. The difficulty of the concept is that students experience errors in writing mathematical forms, and students experience errors in understanding the meaning of the problem. The principal difficulty faced by students is experiencing errors in calculating the final results. The findings in this study are to find and analyze the forms of difficulty of concepts and principles that elementary school students do in solving word problems with integers. However, the forms of difficulty found are still based on some elementary school students. In addition, this study has not generally identified the relationship between knowledge and the difficulty of students' concepts and principles in solving word problems. Therefore, it is suggested for the next research to do a statistical analysis between the relationship or the influence of knowledge of concepts and principles of elementary school students on the difficulties in solving word problems. The implications of the results of this study prove that elementary school students can solve problems in the form of word problems, although there are still errors in the solution. Thus, educators and practitioners need to focus on teaching material and familiarize elementary school students to obey the steps for solving word problems. 


\section{REFERENCES}

Achmetli, K., Schukajlow, S., \& Rakoczy, K. (2018). Multiple solutions for realworld problems, experience of competence and students' procedural and conceptual knowledge. International Journal of Science and Mathematics Education, 17(8), 1605-1625. https://doi.org/10.1007/ s10763-018-9936-5.

Al-Mutawah, M. A., Thomas, R., Eid, A., Mahmoud, E. Y., \& Fateel, M. J. (2019). Conceptual understanding, procedural knowledge, and problem-solving skills in mathematics: High school graduates work analysis and standpoints. International Journal of Education and Practice. https:/ / doi.org/ 10.18488/journal.61.2019.73.258.273.

Aliah, S. N., \& Bernard, M. (2020). Analisis kesulitan siswa dalam menyelesaikan soal pemecahan masalah berbentuk cerita pada materi segitiga dan segiempat. Suska Journal of Mathematics Education, 6(2), 111118. https:/ / doi.org/10.24014/ sjme.v6i2.9325.

Astawa, I. K. P., Suarjana, I. M., \& Murda., I. N. (2016). Analisis kemampuan siswa dalam menyelesaikan operasi bilangan bulat pada siswa kelas $\mathrm{v}$ sd. E-Journal PGSD Universitas Pendidikan Ganesha, 4(1), 1-11. https:// doi.org/10.23887/jjpgsd.v4i2.7697.

Bryant, D. P., Bryant, B. R., Dougherty, B., Roberts, G., Pfannenstiel, K. H., \& Lee, J. (2020). Mathematics performance on integers of students with mathematics difficulties. Journal of Mathematical Behavior, 58(June 2019), 100776. https:// doi.org/10.1016/j.jmathb.2020.100776.

Creswell, J. W. (2012). Educational research: planning, conducting, and evaluating quantitative and qualitative research. Pearson Education.

Culaste, I. C. (2011). Cognitive skills of mathematical problem solving of grade 6 children. International Journal of Innovative Interdisciplinary Research, (1), 120-125.

Dewi, N., Untu, Z., \& Dimpudus, A. (2020). Analisis kesulitan menyelesaikan soal matematika materi operasi hitung bilangan pecahan siswa kelas vii. Jurnal PRIMATIKA, 9(2), 61-70. https://doi.org/10.30872/ primatika.v9i2.217.

Evi, S. (2011). Pendekatan matematika realistik (pmr) untuk meningkatkan kemampuan berfikir siswa di tingkat sekolah dasar. Jurnal Penelitian Pendidikan, Edisi Khus(2), 154-163. 
Fatahillah, A., N.T., Yuli. F. W., \& Susanto. (2017). Analisis kesalahan siswa dalam menyelesaikan soal cerita matematika berdasarkan tahapan newman beserta bentuk scaffolding yang diberikan. Jurnal Kadikma, $8(1), \quad 40-51$. Retrieved from https://jurnal.unej.ac.id/index.php/ kadikma/article/view/5229.

Laily, I. F. (2014). Hubungan kemampuan membaca pemahaman dengan kemampuan memahami soal cerita matematika sekolah dasar. Eduma: Mathematics Education Learning and Teaching, 3(1). https://doi.org/ 10.24235/eduma.v3i1.8.

Levin, M. (2018). Conceptual and procedural knowledge during strategy construction: a complex knowledge systems perspective. Cognition and Instruction. https:// doi.org/10.1080/07370008.2018.1464003.

Lutvaidah, U., \& Hidayat, R. (2019). Pengaruh ketelitian membaca soal cerita terhadap kemampuan pemecahan masalah matematika. JKPM (Jurnal Kajian Pendidikan Matematika), 4(2), 179. https://doi.org/10.30998 /jkpm.v4i2.4189.

Mahmuda, A. A., Astuti, M. D., Mikdadi, A. H., Saputra, A. R. M., \& Darmadi, D. (2021). Analisis kesulitan dalam pembelajaran matematika mengenai materi bilangan bulat di kalangan sd pada masa pandemi. Jurnal Review Pendidikan Dan Pengajaran, 4(1), 90-96. https://doi.org/10.31004/ jrpp.v4i1.1827.

Mandasari, N., \& Rosalina, E. (2021). Analisis kesulitan siswa dalam menyelesaikan soal operasi bilangan bulat di sekolah dasar. Jurnal Basicedu, 5(3), 1139-1148. https://doi.org/10.31004/basicedu.v5i3.831.

Miles, M., Huberman, M., \& Saldana, J. (2013). Qualitative data analysis: a methods sourcebook: an expanded sourcebook. 408.

Mulyati, T. (2016). Kemampuan pemecahan masalah matematis siswa sekolah dasar (mathematical problem solving ability of elementary school students). EDUHUMANIORA: Jurnal Pendidikan Dasar, 3(2), 1-20. https://doi.org/10.17509/eh.v3i2.2807.

Nur, A. S., Kartono, K., Zaenuri, Z., \& Rochmad, R. (2020). The learning trajectory construction of elementary school students in solving integer word problems. Participatory Educational Research, 9(1), 404-424. https:// doi.org/10.17275/ per.22.22.9.1.

Padang, F. T. H., Fuad, Y., \& Ekawati, R. (2018). Reasoning behaviors of 
mathematics difficulties students in solving multiplication integers. 157, 262265. https://doi.org/10.2991/ miseic-18.2018.63.

Powell, S. R., Berry, K. A., \& Benz, S. A. (2020). Analyzing the word-problem performance and strategies of students experiencing mathematics difficulty. Journal of Mathematical Behavior, 58. https:/ / doi.org/10.1016/ j.jmathb.2020.100759.

Pubaningrum, K. (2019). Analisis kesulitan mahasiswa dalam memahami materi kontinuitas fungsi mata kuliah kalkulus diferensial. MATH DIDACTIC: Jurnal Pendidikan Matematika, 5(2), 199-209. https:// doi.org/ 10.33654/math.v5i2.612.

Pujiastuti, H. P. L. S. (2021). Analisis kesulitan siswa kelas v sekolah dasar dalam menyelesaikan soal cerita pada materi bangun ruang. Jurnal Pendidikan Dan Pembelajaran Dasar, 8(1), 65-74. https://doi.org/ 10.24042/terampil.v8i1.9200.

Purwaningtyas, B. A., Sary, R. M., \& Artharina, F. P. (2020). Analysis of misconceptions in FPB and KPK material for students. International Journal of Elementary Education, 4(4), 596-604. https://doi.org/prefix 10.23887/ijee.

Saja'ah, U. F. (2018). Analisis kesulitan siswa kelas iv sekolah dasar dalam menyelesaikan soal pemecahan masalah. EduHumaniora | Jurnal Pendidikan Dasar Kampus Cibiru, 10(2), 98-104. https:/ / doi.org/10.17509 /eh.v10i2.10866.

Sepeng, P., \& Madzorera, A. (2014). Sources of difficulty in comprehending and solving mathematical word problems. International Journal of Educational Sciences, 6(2), 217-225. https://doi.org/10.1080/09751122. 2014.11890134.

Sidik, G. S., \& Wakih, A. A. (2019). Kesulitan belajar matematik siswa sekolah dasar pada operasi hitung bilangan bulat. NATURALISTIC: Jurnal Kajian Penelitian Dan Pendidikan Dan Pembelajaran, 4(1), 461-470. https:/ / doi.org/10.35568/naturalistic.v4i1.633.

Sipayung, T. N., \& Anzelina, D. (2019). An analysis of students' problem solving skills using a realistic mathematics approach on integers materials. Journal of Physics: Conference Series, 1211(1). https://doi.org/ 10.1088/1742-6596/1211/1/012083.

Song, Y. (2018). Improving primary students' collaborative problem-solving 
competency in project-based science learning with productive failure instructional design in a seamless learning environment. Educational Technology Research and Development, 66(4), 979-1008. https://doi.org/ 10.1007/s11423-018-9600-3.

Sovia, A., \& Herman, T. (2019). Slow learner errors analysis in solving integer problems in elementary school. Journal of Engineering Science and Technology, 14(3), 1281-1288.

Syahrir., Kusnadin., \& Nurhayati. (2013). Analisis kesulitan pemahaman konsep dan prinsip materi pokok dimensi tiga siswa kelas xi smk keperawatan yahya bima. Prisma Sains: Jurnal Pengkajian Ilmu Dan Pembelajaran Matematika Dan IPA IKIP Mataram, 1(1), 89. https:// doi.org/ 10.33394/j-ps.v1i1.522.

Verschaffel, L., Schukajlow, S., Star, J., \& Van Dooren, W. (2020). Word problems in mathematics education: a survey. ZDM - Mat.hematics Education, 52(1). https:// doi.org/10.1007/s11858-020-01130-4.

Waskitoningtyas, R. S. (2016). Analisis kesulitan belajar matematika siswa kelas v sekolah dasar kota balikpapan pada materi satuan waktu tahun ajaran 2015/2016. JIPM (Jurnal Ilmiah Pendidikan Matematika), 5(1), 24. https://doi.org/10.25273/jipm.v5i1.852.

Wulandari, L., \& Riajanto, M. L. E. J. (2020). Analisis kesulitan siswa smp dalam menyelesaikan soal materi aritmetika sosial. Jurnal Riset Pendidikan Inovasi Dan Pembelajaran Matematika (JRPIPM), 3(5), 61. https://doi.org/ 10.26740/jrpipm.v3n2.p61-67.

Yusmin, E. (2017). Kesulitan belajar siswa pada pelajaran matematika (rangkuman dengan pendekatan meta-ethnography). Jurnal Visi Ilmu Pendidikan, 9(1), 2119-2136. https:/ / doi.org/10.26418/jvip.v9i1.24806.

Zalima, E. I., Njanji, F. P., Lasmiatik, L., Agustina, L., \& Dela, M. (2020). Analisis kesulitan siswa dalam menyelesaikan soal cerita operasi hitung pada bilangan pecahan campuran. Prismatika: Jurnal Pendidikan Dan Riset Matematika, 2(2), 46-54. https://doi.org/10.33503/prismatika. v2i2.658. 